\title{
DAMPAK IMPLEMENTASI GREEN SHIPPING PADA PERUSAHAAN PELAYARAN
}

\author{
Maulita $\mathbb{1}^{1)}$ dan Minarni Adham $\mathbb{( D}^{2)}$ \\ ${ }^{1,}$ Ketatalaksanaan Pelayaran Niaga dan Kepelabuhan, Politeknik Negeri Samarinda \\ ${ }^{1,2}$ Jl. Ciptomangunkusumo Kampus Gunung Lipan, Samarinda \\ E-mail : maulita@polnes.ac.id ${ }^{1)}$, adham@polnes.ac.id ${ }^{2)}$
}

\begin{abstract}
ABSTRAK
Penelitian ini bertujuan untuk mengevaluasi implementasi Green Shipping pada industri Perkapalan dan Transportasi Laut Kalimantan Timur yang sesuai aturan International Maritime Organization yang dimuat dalam Marine Pollution Regulasi Annex VI. Data yang digunakan dalam penelitian ini adalah data sekunder berupa data spesifikasi kapal TB. Rezky 27. Alat analisis yang digunakan dalam penelitian ini adalah analisis kuantitatif yaitu mengolah data perhitungan jumlah konsumsi bahan bakar, menghitung faktor emisi, simulasi perhitungan penggunaan bahan bakar dan membandingkan biaya konsumsi bahan bakar. Hasil penelitian menemukan bahwa berdasarkan perhitungan konsumsi lima bahan bakar yang dapat digunakan kapal, bahan bakar LNG memiliki biaya konsumsi paling kecil dibanding bahan bakar lainnya namun ketersediaan LNG sebagai bahan bakar alternatif masih kurang untuk memenuhi kebutuhan industri pelayaran selanjutnya biaya konsumsi bahan bakar Solar dan HSFO (High Sulfur Fuel Oil) memiliki biaya yang kecil namun mengharuskan kapal menggunakan scrubber sehingga berdampak pada perusahaan pelayaran yang harus mengeluarkan biaya investasi untuk pembelian Scrubber. Penggunaan bahan bakar methanol sebagai bahan bakar alternatif karena ramah lingkungan dapat digunakan di industri pelayaran namun diperlukan modifikasi dan penyesuaian pada mesin kapal sehingga berdampak pada biaya yang harus ditanggung oleh perusahaan. Penggunaan bahan bakar LSFO (Low Sulfur Fuel Oil) berdasarkan perhitungan konsumsi bahan bakar memiliki biaya yang paling tinggi diantara bahan bakar lainnya namun bahan bakar ini adalah bahan bakar yang sesuai dengan aturan IMO.
\end{abstract}

Kata Kunci: Green Shipping, Imo, Bahan Bakar, SDG's

\section{PENDAHULUAN}

Industri maritim internasional sebagai pemangku kepentingan utama berperan penting dalam keberlanjutan global (Benamara, H., Hoffmann, J., \& Youssef, 2019) Dengan mendukung perdagangan dunia dan memfasilitasi ekonomi global, industri maritim dapat memberikan kontribusi utama pada SDG 14 yang bertujuan khusus untuk konservasi dan pemanfaatan berkelanjutan Samudra, laut dan sumber daya (Cormier \& Elliott, 2017; Recuero Virto, 2018)

Indonesia adalah negara kepulauan terbesar di dunia, sesuai dengan program nawacita pemerintahan Joko Widodo untuk menjalin konektivitas nusantara melalui transportasi maritim menjadi poros utama pemerintah Indonesia untuk mewujudkan cita-cita Indonesia menjadi poros maritim dunia. Indonesia membangun infrastruktur- Infrastruktur maritime yang ramah lingkungan dengan tetap mempertahankan semangat Paris Agreement dalam isu Green House Gases (GHG) untuk mengurangi gas rumah kaca dan mendukung terwujudnya Sustainable Development Goals (SDG's).

Kalimantan timur adalah pulau di indonesia perairan dikelilingi oleh sungai, sehingga banyak aktivitas

Penelitian lain mengenai Green Shipping yang berjudul pengukuran untuk evaluasi implementasi praktik Green Shipping pada industri perkapalan dan pelayaran baik untuk memenuhi kebutuhan transportasi masyarakat dan yang terbesar adalah aktivitas pelayaran dalam mengirim sumber daya alam ke luar daerah yang padat.

Moda transportasi dalam pelayaran memiliki kontribusi yang besar terhadap pencemaran lingkungan karena pada pelayaran yang menjadi komponen biaya terbesar adalah biaya bahan bakar. Menurut (Han, 2010) (Palebangan, 2019)

Kapal merupakan moda transportasi yang paling efisien untuk mengangkut namun menghasilkan emisi dalam persatuan jaraknya. Menurut (European Federation for Transport and environmental AISBL, 2016) emisi yang di ditimbulkan oleh kapal semakin meningkat sedangkan emisi darat turun secara bertahap. Jika dibiarkan pada tahun 2020 pelayaran akan menjadi penghasil emisi terbesar bahkan melampaui emisi yang bisa dihasilkan oleh transportasi darat.

IMO (International Maritime Organization) adalah organisasi dunia yang salah satunya menaungi mengenai pencemaran dalam MARPOL annex VI yang menetapkan standar polusi untuk setiap jenis kapal.

transportasi laut mencakup kebijakan dan prosedur perusahaan, dokumentasi pengiriman, peralatan pengiriman, kerja sama pengiriman dan kepatuhan dan 
memvalidasi nya dengan faktor konfirmasi analisis sehingga berguna untuk mengevaluasi kekuatan dan kelemahan perusahaan pelayaran untuk melaksanakan Green Shipping dan mengidentifikasi bagian yang harus ditingkatkan.(Lai dkk., 2013)

Penelitian selanjutnya mengidentifikasi peraturan san situasi pasar mengenai Green Shipping di negara-negara besar seperti Eropa, Amerika, Jepang, Cina dan Korea selatan. Pada penelitian ini ditemukan enam masalah utama untuk meningkatkan rencana strategis dalam menyiapkan Green Shipping di korea selatan dan untuk menanggulanginya maka perlu dilakukan antara lain pembentukan jaringan kolaboratif pengirimanpembuatan kapal, berbagi informasi dan mengurangi biaya bersama untuk industri pelayaran dan industri pembuatan kapal, melakukan investasi dalam Research and Development untuk kapal ramah lingkungan pada industri pembuatan kapal dan yang terakhir memperluas dukungan untuk kapal dengan bahan bakar LNG.(Lee \& Nam, 2017)

Sustainable Development Goals (SDGs) merupakan agenda yang disepakati secara global dengan tujuan untuk merangsang tindakan menuju keberlangsungan ekonomi, lingkungan dan sosial. Industri kemaritiman internasional memainkan peranan penting dan berkontribusi pada keberlangsungan kehidupan global. Penelitian ini kemudian menguji tanggung jawab dasar dan tanggungan jawab tambahan ada dalam (SDGs 1-6) dan potensi kolaborasi dalam rantai nilai (SDG 17) terkait dengan implementasi Sustainable Development Goals (SDGs) di industri maritim. Dalam penelitian ini ditemukan kerangka kerja terpadu yang diusulkan yang diusulkan, yang menunjuk pada beragam motif dan tingkat kelengkapan upaya keberlanjutan oleh industri maritim. Kerangka kerja ini mengungkapkan proses teoretis keterlibatan transisi industri maritim dalam perspektif SE dan menimbulkan implikasi manajerial mengenai strategi alokasi sumber daya oleh industri maritim dalam memenuhi SDGs.(Wang dkk., 2020)

Dampak transportasi laut terhadap lingkungan sudah berkembang selama 30 tahun terakhir. Fokus utama Green Shipping adalah tentang polusi udara dan klasifikasi praktik Green Shipping seperti tindakan teknis di lapangan, opsi operasional, tindakan berbasis pasar dan daur ulang. Penelitian Green Shipping diharapkan memperkuat penelitian teknologi untuk memecahkan masalah praktis yang dihadapi untuk membangun sistem Green Shipping, sehingga pada akhirnya dapat menetapkan standar dan hukum Pelayaran yang ramah lingkungan.(Shi, W, Xiao, Y, Chen, Z A., McLaughlin, H \& Li, K, 2018)

Industri, pemerintah dan pemangku kepentingan mengklaim perlunya teknologi untuk menggunakan bahan bakar yang aman untuk energi global. Bahan bakar antara lain metanol, gas alam, listrik plug-in, hibrida listrik, hidrogen dan biofuel untuk menggantikan penggunaan bahan bakar fosil di sektor transportasi.(Wan dkk., 2016)

Konsep New Environmental Politics of Urban Development (NEPUD) mempelajari dampak regulasi lingkungan internasional dam nasional terhadap politik pembangunan perkotaan. Penelitian ini dilakukan pada kota pelabuhan yang secara struktural kurang beruntung seperti di Eropa Utara, Hull (Inggris) Bremerhaven (Jerman) yang menyoroti peraturan perubahan iklim untuk menarik "green job" .(Jonas dkk., 2017).(Chang \& Danao, 2017) Circularseas European Project sebagai bagian dari circular ekonomi Uni Eropa bertujuan mempromosikan Green Economy untuk mengembangkan produk hijau, suku cadang dan komponen industri maritim. (Garrido dkk., 2020) Perusahaan pelayaran termotivasi untuk mengadopsi Green Shipping yang ditetapkan oleh lembaga asosiasi. Permintaan pelanggan akan keramahan lingkungan memotivasi perusahaan untuk membuat citra yang baik selain itu praktik Green Shipping ternyata dapat meningkatkan kinerja dan produktivitas perusahaan pelayaran.(Chang \& Danao, 2017)

Pada Jurnal-Jurnal Penelitian terdahulu berkaitan dengan penelitian Green Shipping dapat disimpulkan bahwa beberapa negara sudah menyadari sangat pentingnya pembangunan berkelanjutan (Sustainable Development Goals (SDG's) dengan memperhatikan aspek lingkungan terhadap operasi perusahaan dengan tidak hanya memikirkan kepentingan laba perusahaan namun juga untuk kepentingan publik, namun terdapat beberapa masalah yang harus diperhatikan salah satunya adalah biaya yang ditanggung oleh perusahaan terkait dengan konsep Green Shipping yang sejalan dengan aturan IMO yang harus dipatuhi juga oleh industri pelayaran. Berdasarkan penelitian terdahulu perlu dikaji mengenai pengembangan konsep Green Shipping pada perusahaan pelayaran di Kalimantan Timur karena padatnya aktivitas pelayaran yang ada di sungai Mahakam untuk mendukung konsep pembangunan berkelanjutan (Sustainable Development Goals (SDG's) berkawasan lingkungan yaitu Konsep Green City di Kalimantan Timur.

\section{RUANG LINGKUP}

Ruang lingkup penelitian adalah menentukan kebutuhan perusahaan pelayaran untuk menuju Green Shipping dan kemudian menghitung dampak pembiayaan yang harus ditanggung oleh perusahaan dari aktivitas pelayaran apabila perusahaan menerapkan konsep Green Shipping. Sehingga penelitian ini dapat di formulasikan sebagai opsi bagi perusahaan pelayaran terhadap konsep pembangunan berkelanjutan sustainable Development Goals ( $S D G$ 's) berkawasan lingkungan di Kalimantan Timur. 


\section{BAHAN DAN METODE}

Pada bagian ini menjelaskan bahan-bahan dan metode yang digunakan dalam penelitian ini, diantaranya:

\subsection{Green Shipping}

(Lai, Lun V, Wong, 2013)(Lai, Lun V, Wong, 2013) mengusulkan konseptual untuk mengevaluasi Green Shipping pada praktik perkapalan dan mengembangkan beberapa proposisi agar perusahaan pelayaran akan berperilaku ramah lingkungan dan bertanggung jawab. (Lun, V.Y.H., Lai, K.H. and Cheng, 2015) mengusulkan konsep Greening and Performance Relativity (GPR) dengan menggunakan pendekatan analitis input-output dengan menginvestigasi operasi Hijau (Greening Operation) yang berhubungan dengan kinerja perusahaan survey dilakukan pada industry pelayaran di Hongkong. Hasil penelitian ini menunjukkan bahwa ada hubungan yang positif antara penghijauan dan kinerja perusahaan dalam operasi pelayaran.

\subsection{Regulasi IMO}

Untuk mengurangi emisi maka IMO mengumumkan tiga cara yang bisa dilakukan antara lain, pertama adalah Efisiensi Energi Indikator Operasional Energy Efficiency Design Index (EEDI) yang kedua Efisiensi Energi Kapal (Energy Efficiency Operational) dan Efisiensi manajemen pengelolaan efisiensi energi kapal (Ship Energy Efficiency Management Plant) yang ketiga adalah pengukuran berbasis pasar (Market Based Measured) yang mempertimbangkan pasar karbon, seperti sistem perdagangan emisi sebagai teknis pelengkap dan Langkah-langkah operasional (IMO, 2017)

\subsection{Emisi Gas Buang}

Emisi gas buang merupakan sisa hasil pembakaran kendaraan antara lain kendaraan beroda, kapal/perahu dan pesawat terbang. Pembakaran yang tidak sempurna dari sistem pembuangan dan lapas nya partikel-partikel karena oksigen yang tidak cukup nya dalam proses pembakaran tersebut membuat terbentuknya emisi gas buang.

\subsection{Regulasi Mengenai Emisi Gas Buang}

Terdapat 2 regulasi mengenai emisi gas buang, dijabarkan sebagai berikut:

1. Undang-undang NO. 17 Tahun 2008 mengenai kewajiban setiap awak kapal untuk mencegah dan menanggulangi terjadinya pencemaran lingkungan yang bersumber dari kapal.

2. Peraturan pemerintah Republik Indonesia tentang perkapalan Nomor 51 Tahun 2002 tentang Perkapalan pada pasal 111 (3).

\subsection{Nitrogen Okside (NOx)}

Nitrogen diokside (NOx) merupakan kelompok gas yang terdiri dari gas nitric (NO) dan Nitrogen Diokside
$\left(\mathrm{NO}_{2}\right)$ yang terdapat di dalam atmosfer. Kedua gas ini merupakan yang paling banyak sebagai penyebab polutan udara. Konsentrasi Nitrogen Okside (NO) jumlahnya bervariasi bergantung pada sinar matahari, fenomena meteoreologi dan aktivitas kendaraan. Kedua bentuk nitrogen oksida berbahaya untuk kesehatan manusia. Komponen $\mathrm{NO}_{2}$ empat kali lebih berbahaya dari komponen NO apabila dilihat dari aktivitas mortalitas walaupun belum dilaporkan adanya kematian akibat keracunan Nitrogen Oksida (NO). (Darmayasa, 2013).(Gunawan dkk., 2015)

\subsection{Karbon Monoksida (CO)}

Karbon monoksida merupakan suatu gas yang tidak berbau, tidak berwarna dan tidak memiliki rasa. $\mathrm{CO}$ sebagian besar berasal dari pembakaran bahan bakar fosil dengan udara sehingga menghasilkan gas buangan. CO kebanyakan dihasilkan dari aktivitas kendaraan. Berdasarkan penelitian Gunawan (2015) bahwa terdapat hubungan konsentrasi $\mathrm{CO}$ terhadap beban emisi kendaraan bermotor, kecepatan angin dan temperatur, yang berarti ada hubungan linier dengan konsentrasi CO. (Gunawan dkk., 2015)

\subsection{Sulfur Dioksida (SO2)}

Sulfur Dioksida adalah gas yang berbau sangat tajam namun gas ini tidak terlihat. Sulfur dioksida (SO2) menyebarkan polusi di udara dan juga air hujan dapat membentuk asam sulfur karena hujan asam yang bereaksi dengan air hujan. Aktivitas manusia dan kegiatan industri merupakan sumber penting dari timbulnya gas $\mathrm{SO} 2$. Gas $\mathrm{SO} 2$ sulit dideteksi karena tidak berwarna namun gas $\mathrm{SO} 2$ dapat mengganggu pernafasan, mengakibatkan pencemaran, sakit kepala, sakit dada dan dapat menyerang saraf manusia. Kematian akan terjadi apabila gas $\mathrm{SO} 2$ di ambang batas yang di toleransi.

\subsection{Nitrogen Dioksida}

Bahan Pencemar udara Nitrogen Dioksida (NO2) sangat penting diramalkan hal ini karena udara yang mengandung NO2 apabila memiliki kandungan berlebih akan berbahaya pada kesehatan manusia dan menyebabkan berbagai penyakit kronis seperti emphysema dan bronkitis kronik.(Jusoh dkk., 2020)

\subsection{Metode Penelitian}

Metode penelitian ini menggunakan metode kualitatif dan pendekatan yang digunakan dengan menggunakan model pendekatan studi kasus. Studi kasus merupakan model yang berfokus pada eksplorasi sistem terbatas (bounded system) pada suatu kasus khusus maupun sebagian kasus secara terperinci dan menggali data secara mendalam. Sumber data yang beragam dan kaya akan konteks dilakukan untuk penggalian data (Creswell, 2015). Adapun tahapan dalam penelitian ini antara lain:

1. Identifikasi Masalah

Peneliti pertama kali melakukan tahap identifikasi masalah yaitu mengenai implementasi Konsep Green 
Shipping di perusahaan pelayaran di Samarinda. Oleh sebab itu kemudian identifikasi dan ditemukan beberapa data yang harus didapatkan yaitu apa saja yang menjadi kriteria dari Green Shipping kemudian diperoleh dalam aturan IMO termuat dalam MARPOL Annex VI ada beberapa langkah yang dapat dilakukan untuk mengimplementasikan konsep Green Shipping.

2. Pengumpulan Data

Langkah selanjutnya menentukan sampel dengan teknik purposive yaitu salah satu perusahaan pelayaran di Samarinda yaitu Perusahaan Pelayaran NUR Rezky dengan data kapal TB. Rezky 27 yang merupakan kapal berjenis Tugboat. Data mesin kapal hingga data bahan bakar yang digunakan merupakan data yang akan diolah untuk mengetahui dampak dari Implementasi Konsep Green Shipping pada perusahaan pelayaran.

3. Analisis Data

Data yang peroleh kemudian diolah dengan menggunakan analisis dari peneliti terdahulu yaitu analisis Trozzi et.al untuk menentukan konsumsi bahan bakar dengan jenis kapal Tugboat. Setelah itu dilakukan perhitungan Faktor Emisi pada kapal yang disebabkan oleh aktivitas pelayaran. kemudian dilakukan simulasi perhitungan biaya konsumsi bahan bakar dan membanding jumlah biaya yang ditanggung oleh perusahaan dengan beberapa jenis bahan bakar alternatif. Sehingga kemudian di dalam penelitian ini diperoleh hasil analisis kebutuhan perusahaan pelayaran untuk menuju Green Shipping dan dampak pembiayaan dari aktivitas pelayaran apabila perusahaan menerapkan konsep Green Shipping.

Adapun tahapan penulisan penelitian Konsep Green Shipping pada Perusahaan Pelayaran di Samarinda antara lain:

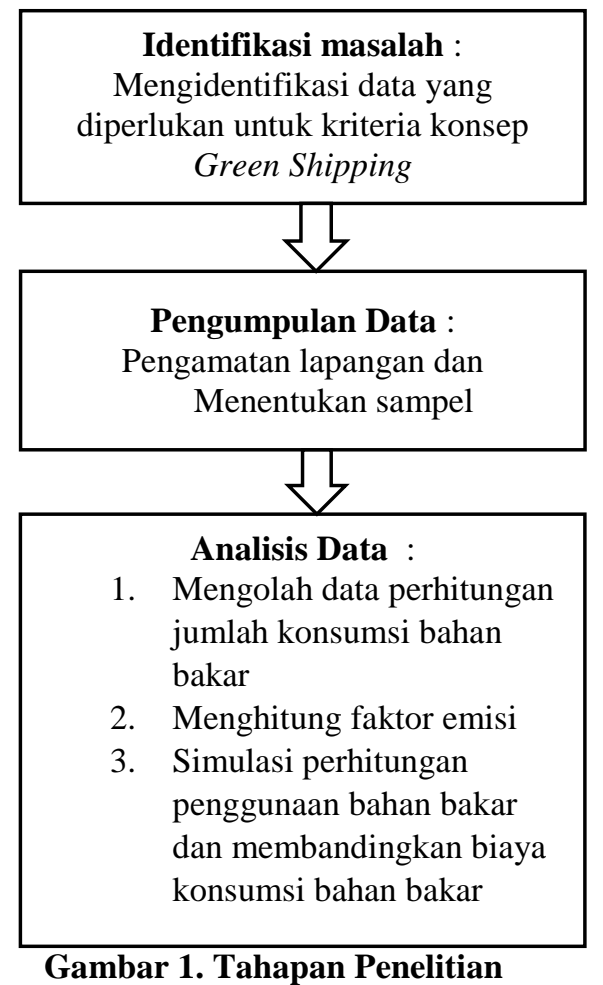

\section{PEMBAHASAN}

Salah satu aturan IMO mengenai Green Shipping adalah mengatur penggunaan bahan bakar dengan kandungan lebih kecil dari $0,5 \%$. Aturan ini diatur dalam aturan Marine Pollution (MARPOL) Annex VI regulasi 14. Untuk mendukung hal tersebut makan kementerian perhubungan juga mengeluarkan aturan Nomor PM 29 tahun 2014 pasal 36 yang mengatur mengenai kandungan sulfur pada bahan bakar kapal 0,5\% yang diberlakukan tanggal 1 januari 2020. Edaran Nomor UM.003/12/DK-19 dari Jenderal Perhubungan Laut menyampaikan hasil sidang komite perlindungan lingkungan perairan (Marine Environment Protection Committee) ke 73 di London.

Penelitian ini dilakukan pada perusahan pelayaran Nur Rezky sebagai sampel untuk menentukan kebutuhan perusahaan apabila menerapkan konsep Green Shipping. Adapun data yang diambil adalah pada TB Rezky 27 yaitu kapal dengan jenis kapal Tugboat. Adapun data mengenai TB rezky 27 terdapat pada tabel 1 . 
Tabel 1. Data kapal TB Rezky 27

\begin{tabular}{|l|l|}
\hline Data Kapal & Keterangan \\
\hline Nama Kapal & Rezky 27 \\
\hline Jenis Kapal & Tugboat \\
\hline Alat Penggerak & $\begin{array}{l}\text { Yuchai YC6754OC 2x 396 } \\
\text { KW }\end{array}$ \\
\hline Angka Huruf Pengenal & YDB 6160 \\
\hline Gross Tonnage & 97 \\
\hline Panjang Kapal & 21.50 \\
\hline Bahan Utama & Baja \\
\hline Jumlah Geladak & 1 \\
\hline Jumlah Baling-Baling & 1 \\
\hline Bahan Bakar & Solar \\
\hline
\end{tabular}

Data pada tabel 1 adalah data spesifikasi kapal sebagai bahan untuk memperkirakan konsumsi bahan bakar sesuai dengan jenis kapal. Selanjutnya dilakukan perhitungan konsumsi bahan bakar TB. Nur Rezky dengan melakukan perhitungan penggunaan konsumsi bahan bakar sesuai jenis kapal. Untuk menghitungnya maka digunakan analisis linier bahan bakar terhadap tonase kotor dari beberapa jenis kapal berdasarkan penelitian Trozzi et.al (Trozzi, 2006) dan hasil perhitungan ada pada tabel 2 .
Tabel 2. Jenis Kapal dan Konsumsi Bahan Bakar

\begin{tabular}{|l|l|}
\hline Jenis Kapal & Keterangan \\
\hline Solid Bulk & $\mathrm{Cjk}=20.1860+0.00049 \times \mathrm{GT}$ \\
\hline Liquid Bulk/Tanker & $\mathrm{Cjk}=14.6850+0.00079 \times \mathrm{GT}$ \\
\hline General Cargo & $\mathrm{Cjk}=9.8197+0.00143 \times \mathrm{GT}$ \\
\hline Container & $\mathrm{Cjk}=8.0552+0.00235 \times \mathrm{GT}$ \\
\hline Ro-Ro Cargo & $\mathrm{Cjk}=12.8340+0.00156 \times \mathrm{GT}$ \\
\hline Passenger & $\mathrm{Cjk}=19.9040+0.00198 \times \mathrm{GT}$ \\
\hline High Speed Ferry & $\mathrm{Cjk}=39.4380+0.00972 \times \mathrm{GT}$ \\
\hline Inland Cargo & $\mathrm{Cjk}=9.8197+0.00143 \times \mathrm{GT}$ \\
\hline Sail Ship & $\mathrm{Cjk}=0.4268+0.00100 \times \mathrm{GT}$ \\
\hline Tugs & $\mathrm{Cjk}=5.6511+0.01048 \times \mathrm{GT}$ \\
\hline Fishing & $\mathrm{Cjk}=1.9387+0.00448 \times \mathrm{GT}$ \\
\hline Other Ship & $\mathrm{Cjk}=9.7126+0.00091 \times \mathrm{GT}$ \\
\hline
\end{tabular}

Berdasarkan analisis linier bahan bakar terhadap tonase kotor pada tabel 2 maka dapat diketahui konsumsi bahan bakar dan selanjutnya adalah melihat faktor emisi pada kapal berdasarkan kegiatan kapal dari berangkat , berlayar sampai berlabuh dengan acuan yang terdapat pada tabel 3 .

Tabel 3. Faktor Emisi Pada Kapal (kg/ton)

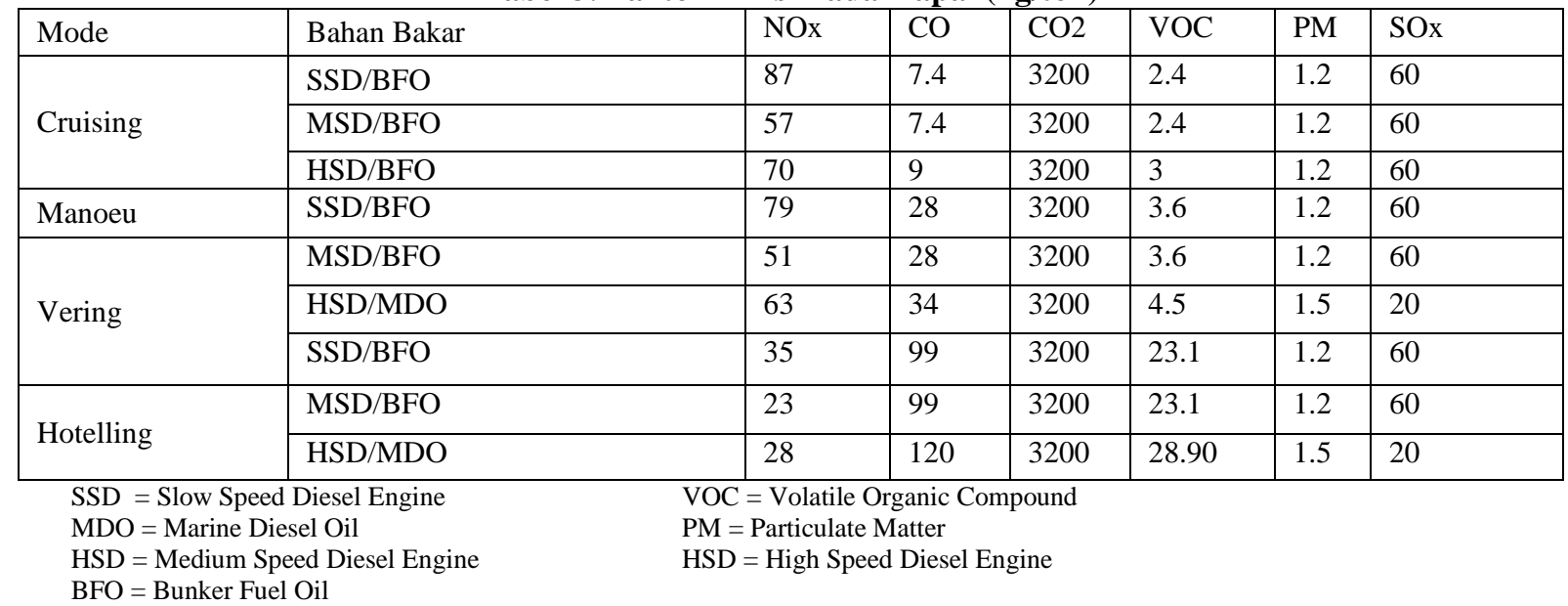

Berdasarkan analisis linier bahan bakar pada tabel 2 maka dapat dihitung konsumsi bahan bakar terhadap tonnase kotor dalam penelitian Trozzi, et.al sehingga dapat dihitung perkiraan konsumsi bahan bakar untuk TB Rezky 27 adalah sebagai berikut, diketahui Gross Tonnage TB Rezky 27 adalah 90 GT sehingga diperoleh perhitungan pada rumus (1).

$$
\begin{aligned}
\mathrm{Cjk} & =5.6511+0.01048 \times \mathrm{GT} \\
& =5.6511+0.01048 \times 90 \\
& =5.6511+1.01656
\end{aligned}
$$

$$
=6.66766 \mathrm{ton} / \mathrm{day}
$$

Berdasarkan hasil perhitungan maka penggunaan bahan bakar menurut analis linier bahan bakar terhadap tonase kotor dalam penelitian Trozzi, et.al adalah sebesar 6.66766 ton/hari. Sehingga berdasarkan data ini kemudian dapat dihitung Faktor Emisi yang dihasilkan kapal dengan (kg/ton) dengan 4 kegiatan yaitu Cruising, Manoeu, Vering dan Hotteling pada TB. Rezky 27. Data perhitungan faktor Emisi untuk kapal TB Rezky 27 dapat dilihat pada tabel 4 . 
Tabel 4. Faktor Emisi Pada Kapal (kg/ton)

\begin{tabular}{|l|l|l|l|l|l|l|l|}
\hline Mode & Bahan Bakar & NOx & CO & CO2 & VOC & PM & SOx \\
\hline \multirow{4}{*}{ Cruising } & SSD/BFO & 580 & 49 & 21.336 & 16 & 8.0 & 400 \\
\cline { 2 - 8 } & MSD/BFO & 380 & 49 & 21.336 & 16 & 8.0 & 400 \\
\cline { 2 - 8 } & HSD/BFO & 466 & 60 & 21.336 & 20 & 8.0 & 400 \\
\hline Manoeu & SSD/BFO & 526 & 187 & 21.336 & 24 & 8.0 & 400 \\
\hline \multirow{3}{*}{ Vering } & MSD/BFO & 340 & 187 & 21.336 & 24 & 8.0 & 400 \\
\cline { 2 - 8 } & HSD/MDO & 420 & 227 & 21.336 & 30 & 10 & 133 \\
\cline { 2 - 8 } & SSD/BFO & 233 & 660 & 21.336 & 154 & 8.0 & 400 \\
\hline \multirow{2}{*}{ Hotelling } & MSD/BFO & 153 & 660 & 21.336 & 154 & 8.0 & 400 \\
\cline { 2 - 8 } & HSD/MDO & 186 & 800 & 21.336 & 192 & 10 & 133 \\
\hline
\end{tabular}

Berdasarkan tabel faktor emisi diatas maka untuk menghindari pencemaran emisi pada kapal, maka ada 3 yang bisa ditempuh perusahaan pelayaran untuk menerapkan konsep Green Shipping yang sesuai dengan aturan IMO Global Shulpur 0,5\%.

Untuk mendukung gerakan "Green Shipping". Adapun langkah tersebut antara lain:

1. Menggunakan bahan bakar LNG yang disebut juga (Low Flashpoint Fuel) yaitu bahan bakar bertitik nyala rendah. Bahan bakar ini yaitu bahan bakar methanol. IGF Code (International code for ships using gases and other low flashpoint fuels) untuk regulasi penggunaan methanol yang diadopsi tahun 2015 (Fachrudiin, 2020)

2. Menggunakan bahan bakar yang berkadar low sulphur fuel dibawah 0,5\%. MGO (Marine Gas Oil) atau distillate fuel adalah jenis dari Low sulfur fuel. Namun kendala yang akan dialami oleh perusahaan pelayaran adalah harganya yang lebih mahal dan ketersediaan nya yang diragukan oleh perusahaan pelayaran karena tidak banyak refinery (produsen BBM) yang memproduksi bahan bakar jenis MGO dengan tetap menjaga keekonomian bisnisnya (Simandjuntak, M., Malau A. G., Kalangie, T.J. F., 2019) (Fachrudiin, 2020)

3. Penggunaan scrubber untuk kapal dengan bahan bakar High Sulphur Fuel Oil (HSFO), alat ini berpotensi mereduksi polusi laut sehingga perlu dipasang sistem scrubber di dalam kapal.(Fachrudiin, 2020).

Untuk menerapkan konsep Green Shipping maka perusahaan dapat melakukan beberapa cara. Dari cara yang ditawarkan pemilihan bahan bakar yang diajukan IMO dalam Marpol Annex VI adalah bahan bakar ramah lingkungan, namun penerapan konsep Green Shipping berdampak pada pembiayaan yang harus ditanggung oleh perusahaan karena konsumsi bahan bakar merupakan biaya yang sangat vital dalam operasional perusahaan pelayaran. Berikut adalah tabel perbandingan harga bahan bakar yang saat ini digunakan serta bahan bakar alternatif yang dapat digunakan pada perusahaan pelayaran Nur Rezky pada kapal mereka jenis Tugboat TB. Nur Rezky. Tabel 5 memperlihatkan perbandingan harga bahan bakar.

Tabel 5. Perbandingan Harga Bahan Bakar

\begin{tabular}{|l|r|}
\hline \multicolumn{1}{|c|}{ Jenis Bahan Bakar } & \multicolumn{1}{c|}{ Harga/ton } \\
\hline Minyak Solar (HSD) & $9.600 .000,00$ \\
\hline LNG & $7.000 .000,00$ \\
\hline LSFO & $13.842 .850,00$ \\
\hline HSFO & $12.100 .000,00$ \\
\hline Methanol & $12.963 .240,00$ \\
\hline
\end{tabular}

Berdasarkan data harga bahan bakar pada tabel 5 kemudian disimulasikan dan akan dibandingkan biaya penggunaan bahan bakar yang saat ini digunakan yaitu solar dengan bahan bakar alternatif yang disarankan dalam aturan IMO yang termuat dalam Marpol Annex VI. Berikut adalah rumus perhitungan konsumsi Bahan Bakar berdasarkan dengan data dari TB.. Rezky 27. Untuk menentukan biaya bahan bakar yang dikonsumsi dapat dihitung dengan menggunakan rumus (2).

(2) $\mathrm{FC}=(\mathrm{C}+5 \%) \times \mathrm{FP}$

$$
\begin{aligned}
& \text { Dimana (2) } \\
& \begin{array}{ll}
\text { FC } & =\text { Fuel Cost } \\
\text { C } & =\text { Fuel Consumption/Mass of Fuel(ton) } \\
\text { FB } & =\text { Fuel Price (ton) }
\end{array}
\end{aligned}
$$

Sehingga diperoleh biaya konsumsi bahan bakar seperti pada tabel 6 . 
Tabel 6. Biaya Konsumsi Bahan Bakar

\begin{tabular}{|c|c|c|c|}
\hline Jenis Bahan Bakar & C & FB/ton & FC \\
\hline Minyak Solar (HSD) & 6.71766 & $9.600 .000,00$ & $64.489 .536,00$ \\
\hline LNG & 6.71766 & $7.000 .000,00$ & $47.023 .620,00$ \\
\hline LSFO & 6.71766 & $13.842 .850,00$ & $92.991 .559,73$ \\
\hline HSFO & 6.71766 & $12.100 .000,00$ & $81.283 .686,00$ \\
\hline Methanol & 6.71766 & $12.963 .240,00$ & $87.082 .638,82$ \\
\hline
\end{tabular}

Berdasarkan simulasi perhitungan biaya konsumsi bahan bakar dengan mengambil data perkiraan pada TB. Rezky 27 maka terlihat urutan biaya konsumsi bahan bakar yang harus ditanggung oleh perusahaan pelayaran. penggunaan minyak solar mempunyai biaya yang paling rendah yaitu sebesar Rp. 64.489.536,00 bahan bakar ini merupakan bahan bakar yang digunakan TB. Rezky saat ini. kemudian penggunaan HSFO sebesar Rp 81.283.686,00 kemudian penggunaan methanol sebagai bahan bakar alternatif sebesar Rp 87.082.683,82 dan LSFO sebagai bahan bakar yang dianjurkan aturan IMO memiliki biaya konsumsi tertinggi sebesar Rp 92.991.559,73, sedangkan LNG sebagai bahan bakar alternatif mempunyai biaya yang lebih rendah dari solar yaitu sebesar Rp 47. 023.620,00.

Pada tabel 7 memperlihatkan selisih biaya konsumsi bahan bakar dari bahan bakar yang digunakan perusahaan saat ini yaitu bahan bakar solar dan bahan bakar alternatif sesuai dengan aturan IMO yang termuat dalam Marpol Annex VI.

Tabel 7. Selisih Biaya Konsumsi Bahan Bakar

\begin{tabular}{|c|c|c|c|}
\hline Jenis Bahan Bakar & FC & Harga solar & Selisih \\
\hline LSFO & $92.991 .559,73$ & $64.489 .536,00$ & $28.502 .023,73$ \\
\hline HSFO & $81.283 .686,00$ & $64.489 .536,00$ & $16.794 .150,00$ \\
\hline Methanol & $87.082 .638,82$ & $64.489 .536,00$ & $22.539 .102,82$ \\
\hline
\end{tabular}

Ada beberapa konsekuensi yang harus ditanggung oleh perusahaan pelayaran apabila menerapkan aturan IMO sesuai MARPOL Annex VI yang sesuai dengan konsep Green Shipping :

\section{Penggunaan Scrubber}

Kandungan suphur di dalam spesifikasi minyak yang ditetapkan di indonesia adalah $0,35 \%$. sama halnya dengan MFO (Marine Fuel Oil) yang masuk pada HSFO (High Sulfur Fuel Oil) mempunyai kandungan $3,5 \% \mathrm{~m} / \mathrm{m}$. Produksi MFO yang diproduksi RU IV pertamina cilacap adalah 1,9juta KL/tahun dan digunakan di dalam sebagai bahan bakar dalam pelayaran nasional. (Sudiono, 2019). Berdasarkan aturan IMO yang termuat dalam aturan MARPOL Annex VI untuk bahan bakar HSFO diperbolehkan di gunakan sebagai bahan bakar dengan ketentuan memasang sistem scrubber di dalam kapal untuk mereduksi polusi laut. Hal ini tentunya membuat perusahaan pelayaran mengeluarkan biaya investasi untuk pembelian scrubber sehingga akan memberatkan perusahaan pelayaran. Sedangkan bahan bakar yang banyak tersedia di lapangan saat ini adalah bahan bakar dengan jenis HSFO.

2. Penggunaan Bahan Bakar LNG

Hasil kajian bahan bakar LNG untuk bahan bakar utama kapal dilakukan dan diperoleh dari hasil bahwa penggunaan LNG dibandingkan solar mempunyai selisih biaya mencapai $20 \%$ dan lebih ramah lingkungan serta memenuhi kebijakan IMO yang termuat dalam MARPOL Annex VI (Siahaya, 2014). Sedangkan di dalam penelitian ini tingkat penghematan yang dapat dilakukan perusahaan apabila menggunakan bahan bakar LNG adalah sekitar $70 \%$.

3. Penggunaan Bahan Bakar LSFO

Bahan bakar yang LSFO (Low Sulphur Fuel Oil) adalah bahan bakar yang memiliki bahan bakar dibawah 0,5\% dan sesuai dengan aturan IMO yang termuat dalam MARPOL Annex VI namun jenis bahan bakar ini mempunyai harga yang lebih mahal dari harga bahan bakar lainnya sehingga akan memperberat biaya yang harus ditanggung oleh perusahaan pelayaran. Terlihat dari tabel perbandingan selisih penggunaan konsumsi bahan bakar sebesar Rp 16. 794.150,00.

4. Penggunaan Bahan Bakar Alternatif Methanol

Bahan bakar jenis fosil pada saat ini sudah mulai menipis sehingga industri pelayaran harus mencari bahan bakar alternatif yang ramah lingkungan. Methanol salah satu bahan bakar alternatif untuk karena mempunyai titik nyala rendah dan memberikan pembakaran yang bersih dan diproduksi dari sumber daya alam yang terbarukan yang digunakan sebagai bahan bakar laut. Namun untuk menggunakan bahan bakar methanol diperlukan modifikasi dan penyesuaian pada mesin kapal antara lain pada Fuel Supply System, Cylinder cover 
modification, Fuel injection, sistem nitrogen inert dan blanketing, instalasi high pressure pump, high pressure pipes, methanol storage tank, instalasi grounding dan bonding, instalasi detection dan alarm. Perusahaan akan menanggung biaya untuk modifikasi namun hal tersebut dapat dilakukan. Namun masalah yang dihadapi juga adalah ketersediaan methanol dan tingkat harga methanol yang masih relatif tinggi.

Pada penelitian ini ditemukan bahwa untuk menjalankan konsep Green Shipping pada perusahaan pelayaran di Kalimantan Timur diperlukan beberapa konsekuensi ekonomi yang harus ditanggung oleh perusahaan pelayaran. Apabila perusahaan menggunakan bahan bakar High Speed Fuel Oil (HSFO) dan HSD (Solar) maka investasi scrubber menjadi pertimbangan bagi perusahaan pelayaran. Bahan bakar alternatif methanol dan LNG pada saat ini menjadi bahan bakar alternatif yang ditawarkan karena memiliki tingkat pencemaran yang kecil sehingga sesuai dengan aturan IMO yang ada dalam MARPOL Annex VI yang sejalan dengan konsep green shipping. Pada saat ini pemerintah sedang giat untuk ketersediaan Methanol dan LNG sebagai bahan bakar alternatif pengganti Solar. Berdasarkan perhitungan biaya dengan menggunakan bahan bakar LNG mempunyai biaya yang lebih rendah namun masih terbatas dalam ketersediaan nya. Sehingga untuk perusahaan pelayaran dapat membandingkan dan memutuskan bahan bakar yang mereka gunakan dengan melihat dari sisi infrastruktur dan perspektif ekonomi yang menguntungkan bagi perusahaan mereka dan peduli pada pembangunan berkelanjutan (Sustainable Development Goals (SDG's) berkawasan lingkungan.

Penelitian sebelumnya dilakukan pada negara-negara maju dan ditemukan bahwa diperlukan sinergi pada industri kemaritiman dan keterlibatan semua pihak untuk mendukung implementasi Green Shipping seperti pembentukan jaringan kolaboratif pengirimanpembuatan kapal, berbagi informasi dan mengurangi biaya bersama untuk industri pelayaran dan industri pembuatan kapal serta melakukan investasi dalam Research and Development untuk kapal ramah lingkungan pada industri pembuatan kapal dan yang terakhir memperluas dukungan untuk kapal dengan bahan bakar ramah lingkungan. Hasil penelitian ini sejalan dengan penelitian sebelumnya yang dilakukan bahwa terdapat konsekuensi biaya yang harus ditanggung oleh perusahaan untuk menggunakan bahan bakar sesuai aturan IMO yang termuat dalam MARPOL Annex VI.

\section{KESIMPULAN}

Implementasi konsep Green Shipping ini dianggap penting karena aktivitas pelayaran di Kalimantan Timur khususnya di Samarinda cukup padat sehingga emisi gas buang yang dihasilkan juga semakin banyak. Apabila Pemerintah Kalimantan Timur bertujuan mencapai konsep pembangunan berkelanjutan (Sustainable Development Goals (SDG's) berkawasan lingkungan yaitu Konsep Green City di Kalimantan Timur. Hasil penelitian ini menemukan bahwa terdapat perbedaan biaya untuk penggunaan bahan bakar, bahan bakar LNG memiliki biaya yang paling rendah dibandingkan bahan bakar solar dan HSFO sedangkan methanol dan LSFO memiliki biaya bahan bakar yang lebih mahal dari bahan bakar lainnya. Untuk penggunaan bahan bakar solar dan HSFO memerlukan penggunaan scrubber pada kapal. Sedangkan untuk penggunaan bahan bakar methanol diperlukan modifikasi pada kapal.

Berdasarkan hasil penelitian maka untuk mengimplementasikan konsep Green Shipping maka kebutuhan perusahaan pelayaran di Samarinda adalah dengan mengikuti aturan IMO yang termuat dalam MARPOL Annex VI. Namun untuk melaksanakan aturan tersebut ternyata berdampak pada pembiayaan yang harus ditanggung oleh perusahaan pelayaran. Perbandingan harga bahan bakar dapat menjadi opsi bagi perusahaan pelayaran untuk memilih yang mana lebih menguntungkan bagi perusahaan pelayaran. Ketersediaan bahan bakar ramah lingkungan juga menjadi tanggung jawab Pemerintah sehingga tidak memberatkan pihak perusahaan.

\section{SARAN}

Pada penelitian ini hanya membandingkan penggunaan konsumsi bahan bakar pada lima bahan bakar yang dapat digunakan untuk kapal, belum meneliti faktor lain yang mempengaruhi pembiayaan yang ditanggung oleh perusahaan pelayaran. Sehingga saran untuk penelitian berikutnya dapat dilakukan penelitian mengenai ketersediaan Bahan bakar ramah lingkungan untuk memenuhi kebutuhan bahan bakar kapal di indonesia khususnya di Samarinda. Penelitian ini juga dapat dilanjutkan dengan menghitung biaya investasi serta pengembalian modal pemasangan scrubber maupun modifikasi kapal untuk penggunaan bahan bakar HSFO, methanol dan LNG sehingga dapat diketahui apakah menggunakan bahan bakar ramah lingkungan sesuai aturan IMO untuk jangka panjang akan memberatkan perusahaan atau akan menghemat biaya bahan bakar perusahaan jika dibandingkan dengan bahan bakar yang saat ini digunakan oleh perusahaan.

\section{DAFTAR PUSTAKA}

Benamara, H., Hoffmann, J., Youssef, F.,.2019. Maritime transport: The sustainability imperative. In: Sustainable Shipping. Springer, Cham, pp. 1-31. https://doi.org/10.1007/97/978-3-030-69325-1.

Chang \& Danao. 2017. Green Shipping Practices of Shipping Firms. Journal Sustainability doi:10.3390/su9050829/ 
Cormier, R, Elliot, M.2017. SMART marine goals, targets and management Is SDG 14 operational or aspirational, is Life Below Water sinking or swimming. Maritime Pollutin Bulletin,Volume 123, issues 1-2, 15 October, Bull. 123 (1-2), 2833https://doi.org/10.1016/j.marpolbul.2017.07.060

Creswell, J. (2014). Penelitian Kualitatif \& Desain Riset: Memilih di antara Lima Pendekatan (Edisi Indonesia). Yogyakarta: Pustaka Pelajar.

Darmayasa, I. G. O. (2013). Dampak NOX Terhadap Lingkungan. Kurva Teknik, 2(1), 98-107.

Garrido. 2020. 3D printing as an enabling technology to implement maritime plastic Circular Economy.Procedia Manyfacturing.Volume 51. P. 635-641. https//creativecommons.org/licenses/bync-nd/4.0/.

Gunawan, H., Ruslinda, Y., \& Anggela, Y. (2015). Hubungan Konsentrasi Karbon Monoksida (CO) di Udara Ambien Roadside Dengan Karakteristik Lalu Lintas Di Jaringan Jalan Sekunder Kota Padang. In The 18th FSTPT International Symposium, Unila, Bandar Lampung.

Han, C-H.2010. Stategies to reduce air poluution in shipping industry. The asian Journal of shipping and logistics, 7-29. https :// www .researchgate .net/publication/257737335.

IMO.2017. IMO dan sustainable develpoment: how international shipping and maritime community contribute to sustainable develovment.IMO, London

Jonas, 2017. Climate Change, The Green Economy and Reimagining the city: The Case of Structurally Disadvantaged European Maritime Port Cities. Vol. 148, No. 4. Research Article. DOI:10.12854/erde148-49.

Jusoh, C.K, Hamid, A. 2020. Meramal Bacaan Maksimum Harian Nitrogen Dioksida Menerusi Pendekatan Kalut. Journal of Quality Measurement and Analysis. P. 78-89.

Lai, Lun V, Wong, Cheng.2013. Measures For Evaluating Green Shipping Practices Implementation: Int J. Shipping Transpots Logistics, $\quad$ Vol. $\quad 5, \quad$ No. 2. https://www.inderscienceonline.com/doi/pdf/10.150 4/IJSTL.2013.053251

Lee, T., \& Nam, H. (2017). A study on green shipping in major countries: in the view of shipyards, shipping companies, ports, and policies. The Asian Journal of Shipping and Logistics, 33(4), 253-262.
Lun, V.Y.H., Lai, K.H. and Cheng, T.C.E. (2012a) 'An evaluation of green shipping networks to minimize external cost in the pearl river delta region', Technological Forecasting and Social Change, forthcoming.

Ruerco Virto. 2018. A preliminary assessment of the indicators for sustainable develpoment goal (SDG) 14 "converse and sustanably use the ocean, seas and marine resources for sustainable development, Marine Policy, Volume 98,p (4757).https://doi.org/10.1016/j.marpol.2018.08.036

Shi, W, Xiao,Y, Chen, Z A., McLaughlin,H \& Li, K, S. 2018. Evolution of green shipping research: themes and method. Maritime Policy and management.https://dx.doi.org/10.1080/038839.201 8.1489150.

Simandjuntak, M., Malau A. G., Kalangie, T.J. F., \& Sukmanofith, D. 2019. Kajian Tingkat Kebutuhan Kompetensi Berdasarkan Permenhub NO. PM 7 Tahun 2018 Tentang Rencana Induk Pengembangan SKKNI Sektor Transportasi, (12 (1), 1-14.

Trozzi, C., \& Vaccaro, R. (2006, June). Methodologies for estimating air pollutant emissions from ships: a 2006 update. In Poster presented at 2nd Environment \& Transport Conference (including 15th Transport and Air Pollution conference) (pp. 12-14).

Wahyudi \& Fachrudiin. 2020. Analisis daya dan biaya penggunaan Low Sulfur Fuel Oil (LSFO) dengan High Sulfur Fuel Oil (HSFO) dilengkapi Scrubber pada kapal niaga. Jurnal Dinamika Bahari. Vol.1, NO.1 Edisi Mei 2020: (31-37) e-ISSN: 2722-0621.

Wan.et.al, Moving Beyond Alternative Fuel Hype To Decarbonize Transportation. 2016.Article Number 16013. Doi.10.1038/Nenegy.2016.13.

Wang, X., Yuen, K. F., Wong, Y. D., \& Li, K. X. (2020). How can the maritime industry meet Sustainable Development Goals? An analysis of sustainability reports from the social entrepreneurship perspective. Transportation Research Part D: Transport and Environment, 78, 102173.

\section{UCAPAN TERIMA KASIH}

Ucapan terima kasih peneliti sampaikan kepada Politeknik Negeri Samarinda yang memfasilitasi penelitian ini. 